OnLine Journal of Biological Sciences 10 (3): 126-135, 2010

ISSN 1608-4217

(C) 2010 Science Publications

\title{
Pesticide-Tolerant Bacteria Isolated from Agricultural Canals in the Lower Rio Grande Valley of South Texas
}

\author{
${ }^{1}$ Sandra Puente Aguirre and ${ }^{2}$ Kristine L. Lowe \\ ${ }^{1}$ Anthony Rico Elementary School, Weslaco, TX \\ ${ }^{2}$ Department of Biology, University of Texas-Pan American, \\ 1201 West University, Drive Edinburg, TX 78539 USA
}

\begin{abstract}
Atrazine and oxamyl are commonly-used pesticides in the Lower Rio Grande Valley of South Texas. Problem statement: Pesticides may become environmental contaminants due to overuse, runoff and other mechanisms and may impact non-target organisms and ecosystems. Pesticides may be degraded by indigenous microorganisms or by abiotic means. In this study, waterborne bacteria from agricultural canals were examined to assess potential atrazine and oxamyl degradation in the Lower Rio Grande Valley. Approach: Water samples were collected March 2007 and June 2009 and inoculated onto agar media containing either atrazine or oxamyl to estimate densities of atrazine-tolerant and oxamyl-tolerant bacteria. Bacterial isolates were characterized morphologically by visually observing colony shape and size and by gram-staining. Commercial test strips and microplates were used to differentiate biochemical and nutritional capabilities of bacteria and an inhibition disk assay was employed to determine pesticide sensitivity. Results: Average density of atrazine-tolerant bacteria was 2,233 $\mathrm{cfu} \mathrm{mL}^{-1}$ in March 2007 and 12, $845 \mathrm{cfu} \mathrm{mL}^{-1}$ in June 2009. Average density of oxamyl-tolerant bacteria was $330 \mathrm{cfu} \mathrm{mL}^{-1}$ in 2007 and $1,158 \mathrm{cfu} \mathrm{mL}^{-1}$ in $2009.66 .7 \%$ of bacteria were Gram-negative. Most isolates were resistant to atrazine or oxamyl regardless of which pesticide medium they were originally grown. Only 2 of 30 tested isolates displayed intermediate and sensitive inhibition phenotypes, respectively, to oxamyl. Biochemical profiles were generally $70 \%$ or greater in similarity but still displayed diverse phenotypes. About half of isolates exhibited a unique biochemical phenotypic profile. Microbial communities in the canals could metabolize a variety of organic compounds and demonstrated high carbon substrate utilization and activity. Conclusion: Overall, indigenous pesticide-tolerant microorganisms were present in lowto-moderate densities, displayed diverse phenotypes and were able to use many organic substrates. This may increase the likelihood that atrazine and oxamyl compounds will be degraded in the Lower Rio Grande Valley.
\end{abstract}

Key words: Atrazine, oxamyl, atrazine-tolerant bacteria, Lower Rio Grande Valley

\section{INTRODUCTION}

The Lower Rio Grande Valley (LRGV) of Texas is an important agricultural region for citrus and other domestic crops. Two commonly used pesticides in the LRGV are oxamyl, also known as Vydate $^{\circledR}$ C-LV (Dupont, Wilmington DE) and atrazine (Syngenta, Greensboro NC). Oxamyl (2-(Dimethylamino)-N [[(methylamino)-carbonyl]oxy]-2-oxoethanimidothioic acid methyl ester) is used for the control of nematodes in fruit and vegetable crops and may also inhibit some fungal pathogens (Hofman and Bollen, 1987). Oxamyl is poorly sorbed to soil material thus it is easily moved by soil water and into crop plants. The potential for oxamyl to leach into ground water exists because of the chemical's high water solubility and poor soil sorption. Oxamyl is used principally on citrus and onion crops grown in South Texas; more than $81,000 \mathrm{~kg}$ of oxamyl are used annually throughout the state (Gianessi and Marcelli, 2000).

Atrazine (6-chloro- $\mathrm{N}^{2}$-ethyl- $\mathrm{N}^{4}$-isopropyl-1, 3, 5triazine-2, 4-diamine) is the active ingredient in several herbicides and has many common trade names. It is a restricted-use pesticide due to its potential for ground water contamination. The US Environmental Protection Agency (1984) (USEPA) requires labeling of all atrazine-containing products. Atrazine is used to control broadleaf and grassy weeds in corn, sorghum and

Corresponding Author: Kristine L. Lowe, Department of Biology, University of Texas-Pan American, 1201 West University, Drive Edinburg, TX 78539 USA Tel: +01 (956) 380-8749 Fax: +01 (956) 381-3657 
sugarcane. In the LRGV, atrazine is used as an herbicide mainly for sorghum crops. Approximately 1.3 million $\mathrm{kg}$ of atrazine are applied annually to fields throughout Texas (Gianessi and Marcelli, 2000). Atrazine is highly persistent in soil and moderately soluble in water.

Runoff from LRGV agricultural fields is collected in agricultural canals and ditches which ultimately drain into the Laguna Madre of South Texas and the Gulf of Mexico (Robertson et al., 1992). Runoff water may contain agricultural pesticides from over flooding of fields or rainfall events after pesticide treatments (Wauchope, 1978). These chemicals enter the canals and other water sources where they can be transported some distance from their source and become environmental contaminants (Gonzalez-Pradas et al., 2000; Islam and Tanaka, 2004).

Remediation strategies for pesticide degradation include abiotic and biotic strategies. Sorensen et al. (2005) observed abiotic degradation of several pesticides in the presence of clay minerals. Many microorganisms are able to degrade pesticides and other anthropogenic compounds (Janssen et al., 2005; MorelChevillet et al., 1996; Runes et al., 2003; Faassen and Lebbink, 1984). Microbially-mediated atrazine degradation proceeds enzymatically by several steps that are encoded for by the atz cluster of genes. Genes atzABC are responsible for the formation of cyanuric acid from atrazine via 2 intermediates; genes atzDEF encode for the conversion of cyanuric acid to $\mathrm{CO}_{2}$ and ammonia (Mandelbaum et al., 1993a; 1993b; Radosevich et al., 1995; Wackett et al., 2002). These genes are typically plasmid-based in bacteria although chromosomal elements have been isolated (De Souza et al., 1998a; 1998b; Devers et al., 2005). Several bacterial genera have been shown to degrade atrazine including Pseudomonas, Ralstonia, Clavibacter, Agrobacterium and Alcaligenes (Alvey and Crowley, 1996; Cai et al., 2003; De Souza et al., 1998a; Devers et al., 2005; Gauger et al., 1986; Radosevich et al., 1995; Ros et al., 2006). However, the bacteria must first be able to tolerate and grow in the presence of a pesticide before other biochemical reactions such as degradation can occur.

The objective of this study was to determine the potential for pollutant pesticides in the LRGV to be degraded by indigenous microorganisms. To examine this, agricultural canal water samples from the region were collected and bacteria were isolated that could grow in the presence of oxamyl and atrazine. Isolated bacteria were characterized morphologically and phenotypically using several methods.

\section{MATERIALS AND METHODS}

Sample collection: Canal water samples were collected from four different agricultural canals near the city of Weslaco, TX [26 9'33'N, 97 59'15'W] in March 2007. The canals were within $3 \mathrm{~km}^{2}$ of each other. The same canals were sampled in June 2009. Samples were obtained by fully submersing a clean, sterile $50 \mathrm{~mL}$ plastic tube underneath the water. The lid was removed when the tube was $10 \mathrm{~cm}$ below the water surface to ensure that air was not introduced into the sample. The lid was replaced while submerged and the tube was appropriately labeled and dated. The samples were transported to the lab on ice and processed within $3 \mathrm{~h}$ of collection.

\section{Determination of atrazine and oxamyl} concentrations in water samples: Concentrations of atrazine and oxamyl in 2009 water samples were estimated by High-Performance Liquid Chromatography (HPLC). Water samples collected in March 2007 were not analyzed for pesticide concentration. Atrazine concentrations were estimated using the method of Mandelbaum et al. (1995). Briefly, water samples were extracted in methanol (50:50). Aliquots $(20 \mu \mathrm{L})$ were injected into a Beckman Model 508 HPLC (Beckman Coulter, Brea, CA) equipped with an $\mathrm{C}-18$ analytical column $(4.6 \times 250 \mathrm{~mm}$; Particle size 5 $\mu \mathrm{m})$ at a flow rate of $2 \mathrm{~mL} \mathrm{~min}^{-1}$. Concentrations were estimated from standard curves constructed with diluted atrazine stocks $\left(0,2\right.$ and $\left.5 \mathrm{ng} \mathrm{mL} \mathrm{mL}^{-1}\right)$. Detection was at $220 \mathrm{~nm}$ (Beckman Coulter Model 166 Detector). Oxamyl concentrations were estimated using the procedure of Osman et al. (2009). Water samples were extracted in acetonitrile and water (80:20) and aliquots $(20 \mu \mathrm{L})$ were injected into the same size column as described for atrazine at a flow rate of $\mathrm{mL} \mathrm{min}^{-1}$. Concentrations were estimated from standard curves constructed with diluted oxamyl stocks $(0,2$ and $5 \mathrm{ng}$ $\mathrm{mL}^{-1}$ ). Detection was at $220 \mathrm{~nm}$. Distilled sterile water was used as a control for HPLC assays and did not contain atrazine or oxamyl.

Culturing of pesticide-tolerant bacteria: Two separate batches of a synthetic medium were made to which each pesticide was added, respectively. Stock atrazine and oxamyl were obtained from commercial supply sources and diluted to the manufacturer's recommended field application concentration (see below). The final concentrations and compositions of the media were per liter: $\mathrm{CH}_{3} \mathrm{COO} \mathrm{Na}[15 \mathrm{mM}$,

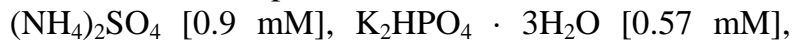
$\mathrm{KH}_{2} \mathrm{PO}_{4}[0.33 \mathrm{mM}], \mathrm{NaHCO}_{3}[0.2 \mathrm{mM}], \mathrm{Na}_{2}$ EDTA . 
$2 \mathrm{H}_{2} \mathrm{O}[7 \mu \mathrm{M}], \mathrm{H}_{3} \mathrm{BO}_{3}[6 \mu \mathrm{M}], \mathrm{FeSO}_{4} \cdot 7 \mathrm{H}_{2} \mathrm{O}[0.6 \mu \mathrm{M}]$, $\mathrm{CoCl}_{2} \cdot 6 \mathrm{H}_{2} \mathrm{O}[0.5 \mu \mathrm{M}], \mathrm{Ni}\left(\mathrm{NH}_{4}\right) \mathrm{SO}_{4}{ }^{2-} \cdot 6 \mathrm{H}_{2} \mathrm{O}[0.5$ $\mu \mathrm{M}], \mathrm{Na}_{2} \mathrm{MoO}_{4} \cdot 2 \mathrm{H}_{2} \mathrm{O}[0.4 \mu \mathrm{M}], \mathrm{Na}_{2} \mathrm{SeO}_{4 \text { (anhyd) }}[0.15$ $\mu \mathrm{M}], \mathrm{MnSO}_{4} \cdot \mathrm{H}_{2} \mathrm{O}[0.13 \mu \mathrm{M}], \mathrm{ZnSO}_{4} \cdot 7 \mathrm{H}_{2} \mathrm{O}[0.1 \mu \mathrm{M}]$, $\mathrm{CuSO}_{4} \cdot 5 \mathrm{H}_{2} \mathrm{O}[0.02 \mu \mathrm{M}]$, casamino acids $[0.01 \% \mathrm{w} / \mathrm{v}]$, Vitamin $\mathrm{B}_{1}\left[0.001 \mathrm{mg} \mathrm{mL}^{-1}\right]$, L-arginine $\mathrm{HCl}[0.02 \mathrm{mg}$ $\mathrm{mL}^{-1}$ ], L-glutamic acid $\left[0.02 \mathrm{mg} \mathrm{mL}^{-1}\right]$, L-glutamine $\left[0.02 \mathrm{mg} \mathrm{mL}^{-1}\right]$, L-serine $\left[0.04 \mathrm{mg} \mathrm{mL} \mathrm{m}^{-1}\right], \mathrm{MgSO}_{4}$ $\cdot 7 \mathrm{H}_{2} \mathrm{O}[1 \mathrm{mM}], \mathrm{CaCl}_{2} \cdot 2 \mathrm{H}_{2} \mathrm{O}[0.5 \mathrm{mM}]$ and $\mathrm{NaCl}[3 \%$ w/v]. Bacto Agar (Difco BBL, Detroit, MI) was added at $15 \mathrm{~g} \mathrm{~L}^{-1}$. Commercial liquid atrazine (approximately $40 \%$ active ingredient) and liquid oxamyl (approximately 10\% active ingredient) were used to amend the medium. After sterilization, either atrazine $(25.3 \mathrm{~mL})$ or oxamyl $(12.7 \mathrm{~mL})$ was added per liter of media. The final concentration of active ingredients was approximately $1 \%$ for atrazine and $0.13 \%$ for oxamyl. The media was allowed to set for $24 \mathrm{~h}$ before sample processing.

Serial dilutions $\left(10^{0}, 10^{-1}, 10^{-2}\right.$ and $\left.10^{-3}\right)$ of canal water samples were made in sterile saline $(0.85 \%)$. A $100 \mu \mathrm{L}$ aliquot of each diluted sample was spread onto the pesticide-amended media. Samples were plated in triplicate and incubated at $25^{\circ} \mathrm{C}$ for one week. Bacterial colonies growing on the plates were counted and the density of atrazine-tolerant and oxamyl-tolerant bacteria in the original water sample was estimated by multiplying the bacterial count times the dilution.

Characterization of atrazine-tolerant and oxamyltolerant bacteria: Randomly selected bacterial colonies were characterized by Gram-stain and by observed colony morphology (i.e., color, size, shape). Selected colonies from atrazine and oxamyl plates were then tested for tolerance to each pesticide using a modification of the Kirby-Bauer method (Madigan et al., 2005). A lawn of each isolate was sub-cultured onto fresh medium that did not contain any pesticide. A $6 \mathrm{~mm}$ disk treated with atrazine and a disk impregnated with oxamyl was placed on each agar plate approximately 4 $\mathrm{cm}$ apart. The plates were incubated at $25^{\circ} \mathrm{C}$ for one week and then observed to see how close the bacterial culture could grow toward the disk. The diameter of the zone of inhibited growth was measured around the disks. A subjective scale was developed to compare the tolerance of each isolate to the two pesticides. Criteria used to determine whether the microbes were tolerant to the pesticides were: cultures with an inhibition zone diameter of $0-5 \mathrm{~mm}$ around the disk were considered pesticide-tolerant $(+)$; Cultures with an inhibition zone between 5.1-10 $\mathrm{mm}$ around the disk were considered intermediate (+/-); Cultures with an inhibition zone> $>10.1$ $\mathrm{mm}$ were termed sensitive (-) to the pesticide.
API 20E ${ }^{\circledR}$ strips: Biochemical profiles for isolates were generated using API $20 \mathrm{E}^{\circledR}$ strips (bioMérieux Inc., Durham, NC). API $20 \mathrm{E}^{\circledR}$ strips include enzymatic tests for fermentation or oxidation of glucose, mannitol, inositol, sorbitol, rhamnose, saccharose, melibiose, amygdalin and arabinose, along with nitrate reduction to nitrite and nitrate reduction to nitrogen gas. API $20 \mathrm{E}^{\circledR}$ strips also test for the presence of $\beta$-galactosidase, arginine dihydrolase, lysine decarboxylase, ornithine decarboxylase, citrate utilization, $\mathrm{H}_{2} \mathrm{~S}$ production, urease, tryptophan deaminase, indole production, acetoin production (Voges-Proskauer) and gelatinase. API $20 \mathrm{E}^{\circledR}$ tests were performed according to the manufacturer's instructions. The number and types of positive tests were tabulated for the isolates and used to construct biochemical phenotypic profiles of the atrazine-tolerant and oxamyl-tolerant cultures. The API $20 \mathrm{E}^{\circledR}$ profiles were used to compare biochemical phenotypes amongst the isolates. A similarity tree among the profiles was constructed using the program NTSYSpc (Exeter Software, Setauket, NY). To construct the similarity tree, an input matrix was constructed with the 21 API $20 \mathrm{E}^{\circledR}$ tests. If a bacterial isolate was positive for that test, the matrix input was ' 1 '. If the isolate was negative for the test, the matrix input was ' 0 '. The NTSYSpc software was then used according to the manufacturer's instructions to produce a similarity matrix and tree. Each isolate's profile was compared to the profile of all the other isolates and reported as a Coefficient of Similarity on a scale of $0.00-1.00$ with 1.00 equal to $100 \%$ similarity.

Community nutrient profile: Water samples collected June 2009 were tested using Biolog EcoPlates ${ }^{\mathrm{TM}}$, which determine the types of carbon substrates that microbial communities can use. EcoPlates $^{\text {TM }}$ are 96-well microplates containing 31 different carbon sources in triplicate with a dye and 3 water (control) wells. The following carbon substrates were available on EcoPlates $^{\mathrm{TM}}$ : $\beta$-Methyl-D-glucoside, D-Galactonic Acid $\gamma$-Lactone, L-Arginine, Pyruvic Acid Methyl Ester, DXylose, D-Galacturonic Acid, L-Asparagine, Tween 40, i-Erythritol, 2-Hydroxy Benzoic Acid, L-Phenylalanine, Tween 80, D-Mannitol, 4-Hydroxy Benzoic Acid, LSerine, $\alpha$-Cyclodextrin, N-Acetyl-D-Glucosamine, $\gamma$ Hydroxybutyric Acid, L-Threonine, Glycogen, DGlucosaminic Acid, Itaconic Acid, L-Glutamic Acid, D-Cellobiose, Glucose-1-Phosphate, $\alpha$-Ketobutyric Acid, Phenylethylamine, $\alpha$-D-Lactose, D,L- $\alpha$-Glycerol Phosphate, D-Malic Acid and Putrescine. If the water microbial community could utilize the carbon source, the microplate well turned purple. The amount of utilization (how well the substrate was used) was 
proportional to the color intensity. Color intensity was quantified by taking the absorbance at $595 \mathrm{~nm}$ using a microplate reader (BioRad Model 680, Hercules, CA). The total activity, equal to the sum of all positive absorbance values, was determined for each sample.

\section{RESULTS}

Atrazine concentrations in 2009 were $0.429,0.183$, 0.422 and $1.24 \mathrm{ng} \mathrm{mL}^{-1}$ in Canals $1,2,3$ and 4, respectively (data not shown). These values were below the USEPA drinking water Maximum Contaminant Level (MCL) of $3 \mu \mathrm{g} \mathrm{L}^{-1}$ (ppb). Oxamyl concentrations were below detection levels. Colony forming units per $\mathrm{mL}$ (cfu $\mathrm{mL}^{-1}$ ) from water samples grown on atrazinecontaining agar media were detected from all 4 sites in March 2007 and June 2009. Bacterial colonies were typically small, round and opaque or yellow in color (Fig. 1). Population estimates for the two sampling times differed. The average density of atrazine-tolerant bacteria was 2,233 $\mathrm{cfu} \mathrm{mL}^{-1}$ in March 2007 and 12,845 cfu $\mathrm{mL}^{-1}$ in June 2009. Atrazine-tolerant bacteria in March 2007 ranged from 1,827-2,667 $\mathrm{cfu} \mathrm{mL}^{-1}$ whereas atrazine-tolerant bacteria in 2009 ranged from 41321,067 cfu $\mathrm{mL}^{-1}$ (Fig. 2). Canal 1 atrazine-tolerant populations were more than 8-fold higher in 2009 than 2007; Samples from Canal 3 were approximately 9-fold higher in 2009 than 2007 (Fig. 2). Population estimates from Canal 4 also increased in 2009 compared to 2007; Canal 2 was the only sample site that showed a decrease in population size from 2007 to 2009 (Fig. 2).

$\mathrm{Cfu} \mathrm{mL}^{-1}$ from water samples grown on oxamylsupplemented agar media were detected in low numbers from all sites in 2007 and from three sites in 2009 (Fig. 3). Bacterial colonies were typically small, round and white in color, or white and filamentous. The average density of oxamyl-tolerant bacteria was $330 \mathrm{cfu}$ $\mathrm{mL}^{-1}$ in 2007 and $1,158 \mathrm{cfu} \mathrm{mL}^{-1}$ in 2009. Oxamyltolerant bacterial population estimates ranged from 77$730 \mathrm{cfu} \mathrm{mL} \mathrm{mL}^{-1}$ in March 2007 (Fig. 3). In June 2009, there were no detectable oxamyl-tolerant bacteria in samples from Canal 2 and cfu $\mathrm{mL}^{-1}$ from canal 4 remained the same as in 2007 (Fig. 3). Oxamyl-tolerant bacteria from Canals 1 and 3 increased 5-fold in 2009 compared to 2007 (Fig. 3).

Gram-staining showed that majority of bacterial isolates were Gram-negative and/or rod-shaped with smaller percentages of Gram-positive and/or coccusshaped cells (Table 1). A few isolates were mixed cultures (mixtures of shapes and gram-stains) and one isolate, S4V2-09 from an oxamyl plate, was a Grampositive spirilla. Gram-negative cells were observed in
$66.7 \%$ of isolated cultures; Gram-positive cells were observed in $26.7 \%$ of cultures; mixed cultures represented $6.7 \%$ of isolated cultures. When isolates were tested for tolerance toward both pesticides, most were resistant to atrazine or oxamyl regardless of which pesticide medium they were originally grown (Table 1). Only two isolates, S2V1-07 and S4A3-07 showed intermediate and sensitive inhibition phenotypes, respectively, to oxamyl. Surprisingly, isolate S2V1-07 was originally grown on oxamyl-containing medium; however, its growth was slower compared to other isolates (data not shown).

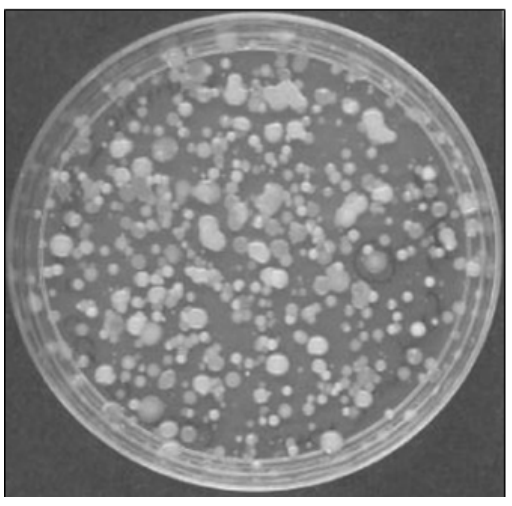

Fig. 1: Representative Petri dish with atrazinecontaining medium showing typical colony growth and colony morphology of bacterial isolates from South Texas agricultural canals

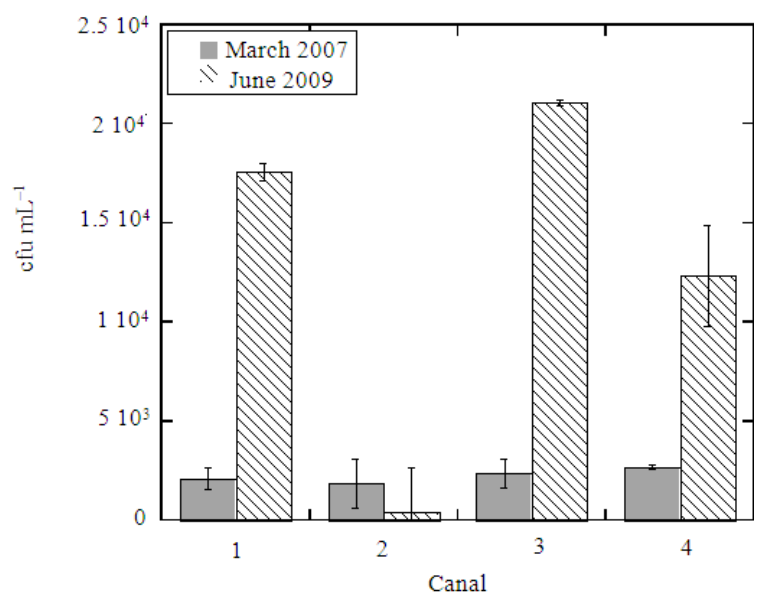

Fig. 2: Density of atrazine-tolerant bacteria from 4 agricultural canals in Weslaco, TX. Water samples were taken in March 2007 and June 2009. Values (cfu $\mathrm{mL}^{-1}$ ) are the mean of triplicate experiments. Error bars $=$ standard deviation 
OnLine J. Biol. Sci., 10 (3): 126-135, 2010

Table 1: Morphology and phenotypes of South Texas canal bacteria isolated on pesticide-containing media. Cultures were examined microscopically for cell shape and gram-stain and assessed for tolerance to Atrazine and Oxamyl using a disk assay

\begin{tabular}{|c|c|c|c|c|c|c|c|}
\hline \multirow[b]{2}{*}{ Isolate } & \multirow[b]{2}{*}{ Canal no. } & \multirow[b]{2}{*}{ Year } & \multicolumn{2}{|c|}{ Gram stain results } & \multicolumn{3}{|c|}{ Tolerance disk assay results $(\mathrm{mm})^{\mathrm{b}}$} \\
\hline & & & Medium & Cell shape & Cell wall type & Atrazine & Oxamyl \\
\hline S1V1-07 & 1 & 2007 & Oxamyl & Coccus & Gram positive & $0(+)$ & $2(+)$ \\
\hline S1V2-07 & 1 & 2007 & Oxamyl & Coccus & Gram positive & $0(+)$ & $0(+)$ \\
\hline S1V3-07 & 1 & 2007 & Oxamyl & Coccus & Gram positive & $0(+)$ & $3(+)$ \\
\hline S2V1-07 & 2 & 2007 & Oxamyl & Coccus & Gram positive & $0(+)$ & $8(+/-)$ \\
\hline S2V2-07 & 2 & 2007 & Oxamyl & Coccus & Gram positive & $0(+)$ & $3(+)$ \\
\hline S3V1-07 & 3 & 2007 & Oxamyl & Coccus & Gram positive & $0(+)$ & $0(+)$ \\
\hline S3V2-07 & 3 & 2007 & Oxamyl & Coccus & Gram positive & $0(+)$ & $1(+)$ \\
\hline S3V3-07 & 3 & 2007 & Oxamyl & Coccus & Gram negative & $0(+)$ & $1(+)$ \\
\hline S4V1-07 & 4 & 2007 & Oxamyl & Coccus & Gram positive & $0(+)$ & $2(+)$ \\
\hline S4V2-07 & 4 & 2007 & Oxamyl & Coccus & Gram positive & $0(+)$ & $1(+)$ \\
\hline S1A1-07 & 1 & 2007 & Atrazine & Rod & Gram negative & $2(+)$ & $3(+)$ \\
\hline S1A2-07 & 1 & 2007 & Atrazine & Rod & Gram negative & $2(+)$ & $3(+)$ \\
\hline S2A1-07 & 2 & 2007 & Atrazine & Rod & Gram negative & $0(+)$ & $2(+)$ \\
\hline S2A2-07 & 2 & 2007 & Atrazine & Rod & Gram positive & $0(+)$ & $5(+)$ \\
\hline S2A3-07 & 2 & 2007 & Atrazine & Rod & Gram negative & $0(+)$ & $3(+)$ \\
\hline S3A1-07 & 3 & 2007 & Atrazine & Rod & Gram negative & $0(+)$ & $2(+)$ \\
\hline S3A2-07 & 3 & 2007 & Atrazine & Rod & Gram negative & $0(+)$ & $1(+)$ \\
\hline S4A1-07 & 4 & 2007 & Atrazine & Rod & Gram positive & $0(+)$ & $3(+)$ \\
\hline S4A2-07 & 4 & 2007 & Atrazine & Rod & Gram positive & $0(+)$ & $2(+)$ \\
\hline S4A3-07 & 4 & 2007 & Atrazine & Rod & Gram negative & $0(+)$ & $12(-)$ \\
\hline S1A1-09 & 1 & 2009 & Atrazine & Rod & Gram negative & & \\
\hline S1A2-09 & 1 & 2009 & Atrazine & Rod & Gram negative & & \\
\hline S1A3-09 & 1 & 2009 & Atrazine & Rod & Gram negative & & \\
\hline S1A4-09 & 1 & 2009 & Atrazine & Rod & Gram negative & & \\
\hline S1A5-09 & 1 & 2009 & Atrazine & Rod & Gram negative & $0(+)$ & $0(+)$ \\
\hline S2A1-09 & 2 & 2009 & Atrazine & Mixed & Mixed & & \\
\hline S2A2-09 & 2 & 2009 & Atrazine & Coccus & Gram positive & & \\
\hline S2A3-09 & 2 & 2009 & Atrazine & Coccus & Gram positive & & \\
\hline S2A4-09 & 2 & 2009 & Atrazine & Rod & Gram negative & & \\
\hline S2A5-09 & 2 & 2009 & Atrazine & Rod & Gram negative & & \\
\hline S2A6-09 & 2 & 2009 & Atrazine & Rod & Gram negative & & \\
\hline S2A7-09 & 2 & 2009 & Atrazine & Rod & Gram negative & & \\
\hline S2A8-09 & 2 & 2009 & Atrazine & Rod & Gram negative & $0(+)$ & $0(+)$ \\
\hline S2A9-09 & 2 & 2009 & Atrazine & Mixed & Mixed & $0(+)$ & $4(+)$ \\
\hline S2A10-09 & 2 & 2009 & Atrazine & Rod & Gram negative & & \\
\hline S3A1-09 & 3 & 2009 & Atrazine & Rod & Gram negative & $0(+)$ & $0(+)$ \\
\hline S3A2-09 & 3 & 2009 & Atrazine & Rod & Gram negative & & \\
\hline S3A3-09 & 3 & 2009 & Atrazine & Rod & Mixed & & \\
\hline S3A4-09 & 3 & 2009 & Atrazine & Rod & Gram negative & & \\
\hline S3A5-09 & 3 & 2009 & Atrazine & Rod & Gram negative & & \\
\hline S4A1-09 & 4 & 2009 & Atrazine & Rod & Gram negative & $0(+)$ & $0(+)$ \\
\hline S4A2-09 & 4 & 2009 & Atrazine & Mixed & Mixed & & \\
\hline S4A3-09 & 4 & 2009 & Atrazine & Rod & Gram negative & $0(+)$ & $0(+)$ \\
\hline S4A4-09 & 4 & 2009 & Atrazine & Coccus & Gram positive & & \\
\hline S4A5-09 & 4 & 2009 & Atrazine & Rod & Gram negative & & \\
\hline S1V1-09 & 1 & 2009 & Oxamyl & Rod & Gram negative & $0(+)$ & $0(+)$ \\
\hline S1V2-09 & 1 & 2009 & Oxamyl & Rod & Gram negative & & \\
\hline S1V3-09 & 1 & 2009 & Oxamyl & Rod & Gram negative & & \\
\hline S1V4-09 & 1 & 2009 & Oxamyl & Rod & Gram negative & & \\
\hline S1V5-09 & 1 & 2009 & Oxamyl & Rod & Gram negative & & \\
\hline S3V1-09 & 3 & 2009 & Oxamyl & Rod & Gram negative & $4(+)$ & $0(+)$ \\
\hline S3V2-09 & 3 & 2009 & Oxamyl & Rod & Gram negative & & \\
\hline S3V3-09 & 3 & 2009 & Oxamyl & Rod & Gram negative & & \\
\hline S3V4-09 & 3 & 2009 & Oxamyl & Rod & Gram negative & & \\
\hline S3V5-09 & 3 & 2009 & Oxamyl & Rod & Gram negative & & \\
\hline S4V1-09 & 4 & 2009 & Oxamyl & Rod & Gram negative & & \\
\hline S4V2-09 & 4 & 2009 & Oxamyl & Spirilla & Gram positive & $0(+)$ & $0(+)$ \\
\hline S4V3-09 & 4 & 2009 & Oxamyl & Rod & Gram negative & & \\
\hline S4V4-09 & 4 & 2009 & Oxamyl & Rod & Gram negative & $0(+)$ & $0(+)$ \\
\hline S4V5-09 & 4 & 2009 & Oxamyl & Rod & Gram negative & & \\
\hline
\end{tabular}

${ }^{a}$ : Twenty isolates from 2007 were examined using the disk inhibition assay. Ten (10) isolates were tested in $2009 ;^{\text {b }}: \mathrm{n}$ inhibition zone diameter of 0-5 $\mathrm{mm}$ around the disk was considered pesticide-tolerant (+); An inhibition zone between 5.1-10 mm around the disk was considered intermediate (+/-); an inhibition zone>10.1 mm was considered sensitive (-) to the pesticide 
Fifty seven pesticide-tolerant isolates were tested using API $20 \mathrm{E}^{\circledR}$ strips in order to construct biochemical profiles of the organisms. The microorganisms were isolated using either atrazine-containing media or oxamyl-containing media during 2007 (20 isolated bacteria) or 2009 (39 isolated bacteria). The API $20 \mathrm{E}^{\circledR}$ profiles were qualitatively compared to construct a Coefficient of Similarity tree (Fig. 4). The tree showed that bacterial isolates clustered together in groups, generally showing $70 \%$ or greater similarity. The clusters contained mixtures of isolates from 2007 and 2009, mixtures from the 4 canal sites and mixtures originally grown on atrazine or oxamyl. The API $20 \mathrm{E}^{\circledR}$ strip profiles showed that there was a range of diversity amongst the isolates with about half displaying a unique biochemical phenotypic profile.

EcoPlate $^{\mathrm{TM}}$ microbial community analysis showed that the total microbial communities in the four canals were able to utilize a variety of carbon substrates; However, the degree of utilization was different among the sites. The microbial community inhabiting Canal 1 was able to use 16 of 31 tested carbon substrates at low levels (Fig. 5a).

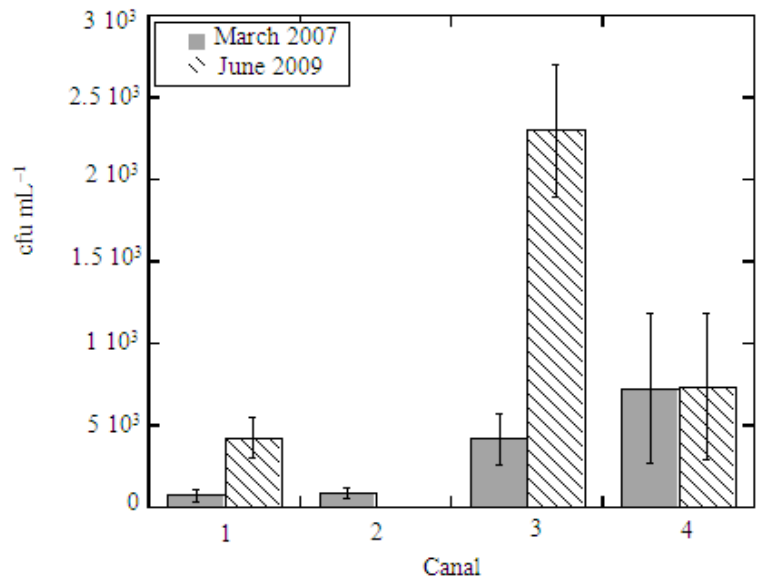

Fig. 3: Density of oxamyl-tolerant bacteria from 4 agricultural canals in Weslaco, TX. Water samples were taken in March 2007 and June 2009. Values (cfu $\mathrm{mL}^{-1}$ ) are the mean of triplicate experiments. Error bars $=$ standard deviation. Note the difference in scale of the yaxis compared to Fig. 2

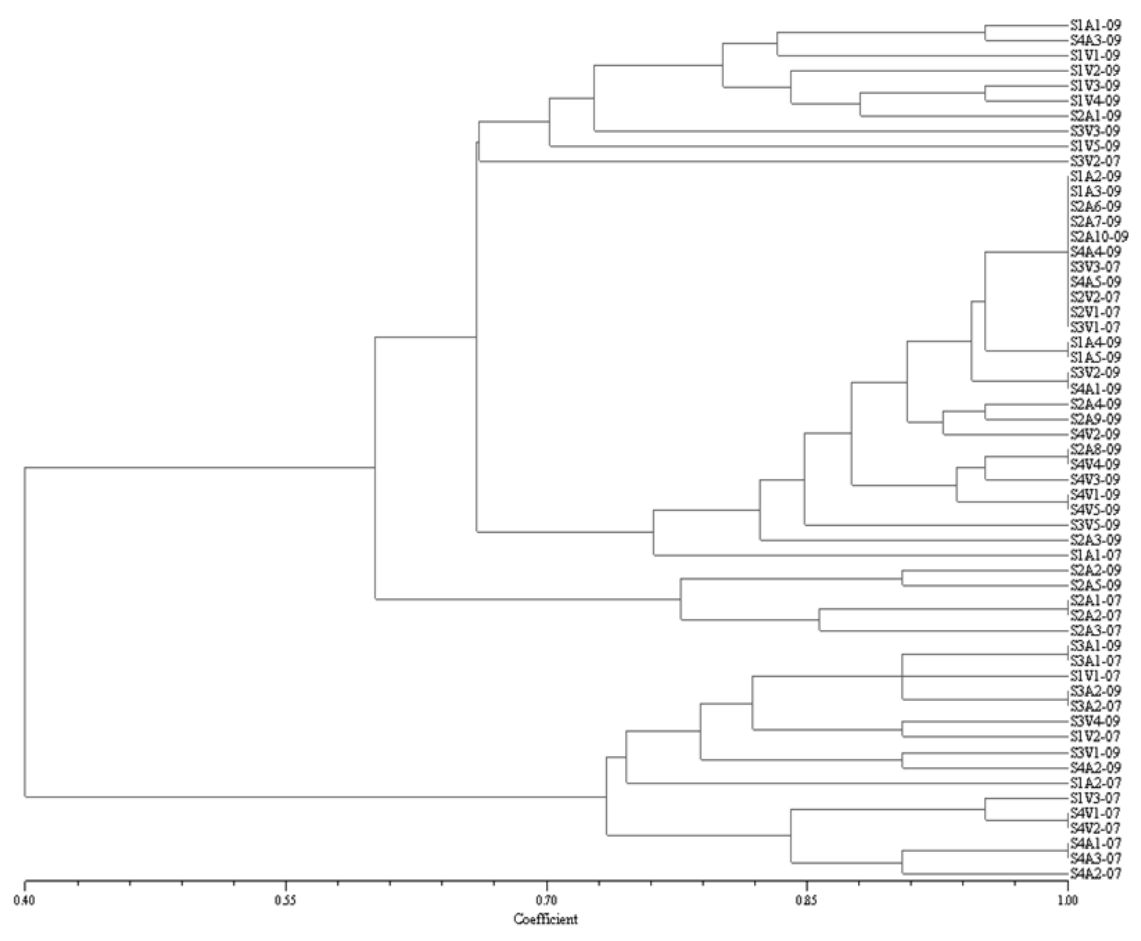

Fig. 4: Similarity tree of biochemical profiles of Atrazine-tolerant and oxamyl-tolerant bacteria cultures isolated from agricultural canals in South Texas. Fifty seven (57) isolates were profiled using API20E ${ }^{\circledR}$ commercial test strips. The tree was produced using NTSYSpc software (Exeter Software, Setauket, NY). The bottom axis shows the degree of similarity among the isolates $(1.00=100 \%)$. Abbreviations: $\mathrm{S} 1=$ Canal $1 ; \mathrm{S} 2=$ Canal 2; S3 = Canal 3; S4 = Canal 4; $\mathrm{A}=$ organism isolated on atrazine media; $\mathrm{V}=$ organism isolated on oxamyl media; Number = isolate number; $-07=$ isolated in March 2007; $-09=$ isolated in June 2009 
OnLine J. Biol. Sci., 10 (3): 126-135, 2010

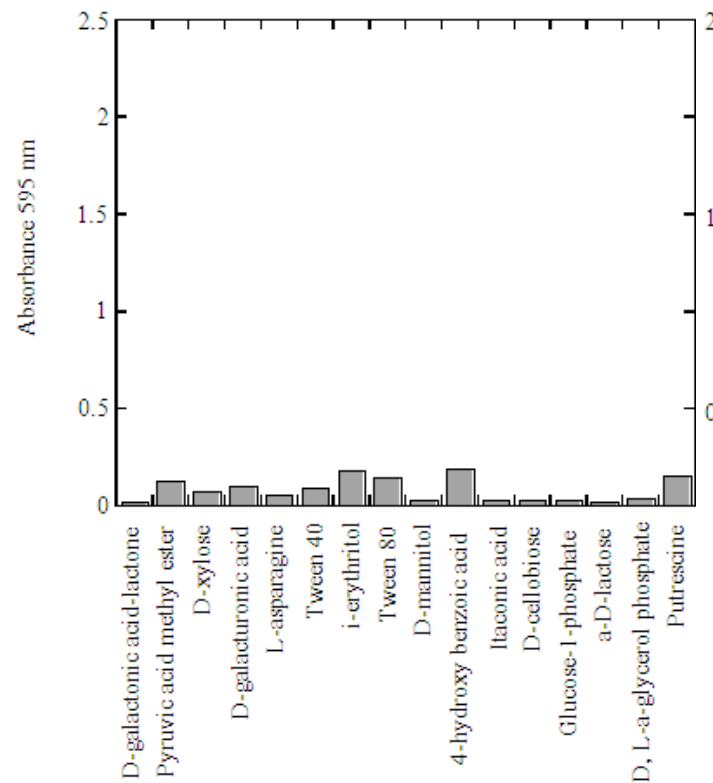

(a)

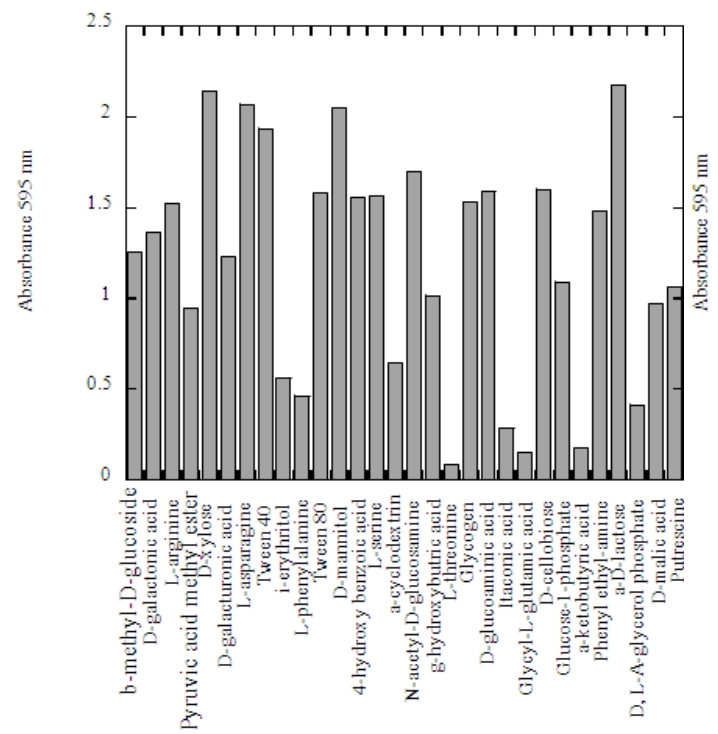

(c)

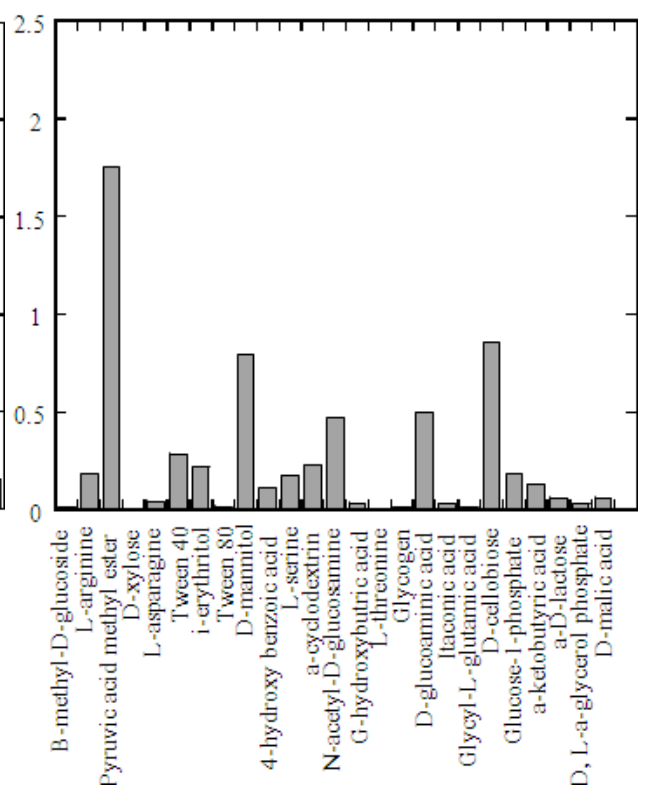

(b)

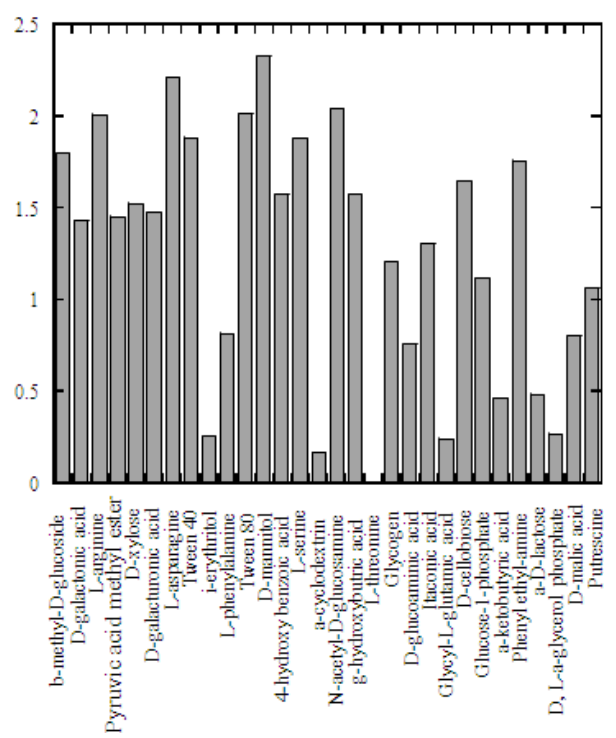

(d)

Fig. 5: EcoPlate ${ }^{\mathrm{TM}}$ profiles of total water-borne microbial communities from South Texas agricultural canals. The intensity of substrate utilization was quantified by absorbance at $595 \mathrm{~nm}$. Values are the mean of triplicate measurements. Panel a: Canal 1 community substrate utilization; Panel b: Canal 2 community substrate utilization; Panel c: Canal 3 community substrate utilization; Panel d: Canal 4 community substrate utilization

This was indicated qualitatively by color changes in the microplate wells and by positive absorbance values for these carbon sources. The absorbance values for Canal 1 were generally low compared to the other canals. The average absorbance value was 0.084 and the highest absorbance value (0.195) was observed in the well corresponding to 4-Hydroxybenzoic Acid.
The microbial community of Canal 2 was able to utilize 26 of 31 tested carbon substrates (Fig. 5b). The average absorbance value was 0.234 and the highest absorbance value (1.752) was observed in the well for Pyruvic Acid Methyl Ester indicating that this substrate was readily metabolized by the canal microbial community. 


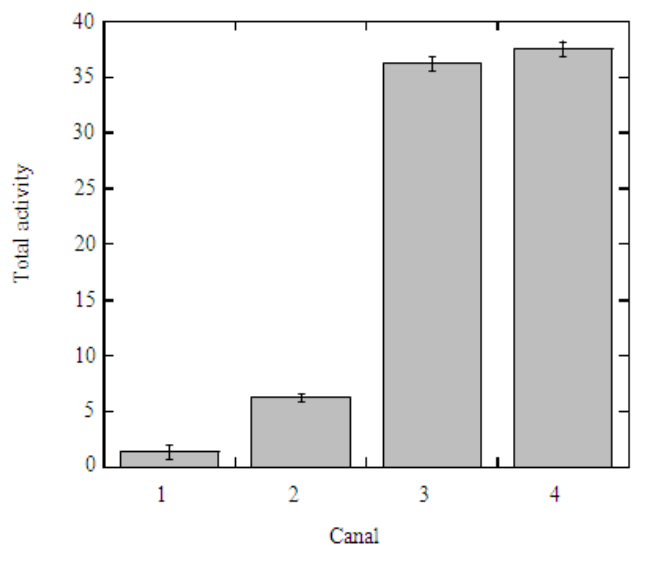

Fig. 6: Total carbon utilization activity of South Texas agricultural canal microbial communities. Values are the sum of the mean values in Fig. 5 with standard deviation

The microbial community of Canal 3 was able to utilize 30 of the 31 tested substrates most of which resulted in absorbance values greater than 1 (Fig. 5c). The average absorbance value was 1.207 and the best utilized substrate for Canal 3 was $\alpha$-D-Lactose (absorbance $=2.174)$.

The microbial community of Canal 4 displayed the best carbon utilization profile of all the sites. The microbial community was able to utilize 30 of 31 substrates with the highest absorbance value (2.325) observed for D-Mannitol (Fig. 5d). The average absorbance value was 1.25 . The total activity (sum of positive absorbance values) was greatest for Canal 4's microbial community followed closely by the community for Canal 3 (Fig. 6). The microbial community total activities for Canals 1 and 2 were approximately $6-27 \mathrm{X}$ lower than the communities of the Canals 3 and 4.

\section{DISCUSSION}

Pesticide use is common in contemporary agriculture and increases crop yields by decreasing losses due to weeds, insects and other pests and decreasing costs (Gianessi and Sankula, 2003; Moens et al., 2004; Taylor, 2003). However, pesticides may inadvertently be transferred to the environment where they can impact non-target organisms (Clarkson et al., 1982; Hofman and Bollen, 1987; Downing et al., 2004). To lessen the potential impact, it is advantageous to have pesticidedegrading microorganisms present in the environment that can convert these compounds to less harmful forms. It is especially advantageous if the indigenous microorganisms are present in high densities and/or show diverse phenotypes. This may increase the likelihood that anthropogenic compounds will be metabolized. The first step in the process must be that the organisms be able to tolerate the compound of interest.

Bacteria have several mechanisms that allow them to be tolerant or resistant to toxic compounds. Bacteria may utilize efflux pumps, which remove toxic compounds from the cell (Silver and Phung, 1996). Bacteria may alter surface receptor sites to block entry into the cell or alter the chemical by mechanisms such as methylation (Bentley and Chasteen, 2002; McBride and Wolfe, 1971). Bacteria may also produce degrading enzymes that metabolize the compound (Talaro, 2008). The latter mechanism is employed in atrazine degradation.

Atrazine and oxamyl are used throughout Texas and specifically in the LRGV for citrus, onion, sorghum and corn crops. Excess amounts of these pesticides may be present in local waterways including those that drain into the Laguna Madre, a rare, important hypersaline estuarine ecosystem along the Texas coast. The Laguna Madre provides habitat to several rare, threatened and endangered species and is along the migratory route of several types of waterfowl. Pesticides, such as atrazine and oxamyl, may have deleterious effects on non-target organisms in and around the Laguna Madre. Oxamyl's mode of action is that of a neurotoxin; thus, it may have negative effects on aquatic fauna. Atrazine, an herbicide, may harm seagrass beds (Thalassia testudinum) in the Laguna Madre, which provide much of the primary production in the ecosystem and are a source of food and habitat for aquatic organisms. Recent observations in the Laguna Madre have a noted a decrease in seagrass beds in some locations (personal communication). Whether this is from an accumulation of pollutants, like pesticides, or some other mechanism (s), is unclear at this time.

Pesticide-tolerant bacterial communities were isolated from four South Texas agricultural canals. Community densities varied by location and sample year. This may have been due to the season and the growing season. Temperature, precipitation and nutrient differences may influence the bacterial communities. Samples were taken in March (2007), before the onset of the agricultural season and June (2009) during the peak of the growing season--a time in which pesticide use would be occurring. Thus, it would be expected that bacterial densities would be higher in June than March due to increased temperatures and the presence of pesticides in the canal waters. Indeed, this was the case. Densities of atrazine-tolerant bacteria were as much as 9-fold higher in the June samples than in the March samples. Oxamyl-tolerant bacterial densities were also generally higher in June than March, with one exception, Canal 2. 
Atrazine-tolerant and oxamyl-tolerant bacterial isolates showed a high degree of diversity with regards to their nutrient utilization, biochemical phenotypes and tolerance toward both pesticides, despite somewhat similar colony and cell morphologies. This gives support to the hypothesis that diverse indigenous microbial communities will increase the likelihood that these pesticides are metabolized. Tests are underway to confirm this.

The atrazine-tolerant and oxamyl-tolerant isolates are currently being assessed for atrazine degradation rates and the formation of intermediates like cyanuric acid and screened for the presence of the atzABC genes either on plasmids or encoded on the bacterial chromosome. Oxamyl degradation genes have yet to be described in the scientific literature. Plasmid-based genes, if present, are potentially transferable to other organisms via horizontal gene transfer. This has been observed in soil microbial communities (Devers et al., 2005). If such genetic events are taking places in South Texas waterways, this could be beneficial to the fate of anthropogenic compounds in the environment of the LRGV.

\section{CONCLUSION}

Atraine-tolerant and oxamyl-tolerant bacteria are present in agricultural canals in the Lower Rio Grande Valley of South Texas. The density of the atrazinetolerant and oxamyl-tolerant populations varied by location and season. Bacteria displayed resistance to both pesticides and diverse biochemical phenotypes. This may increase the likelihood that excesses of these pesticides will be degraded in the environment.

\section{ACKNOWLEDGEMENT}

The researcher gratefully acknowledges Ibdanelo Cortez for performing HPLC assays and Thomas Eubanks, Carol Dracy and Monica Garcia for their assistance. This study was conducted as part of the South Texas Research Internships for the Development of Educators in Science (STRIDES) program at the University of Texas-Pan American generously funded by the Howard Hughes Medical Institute (HHMI) Undergraduate Science Education Program Grant (\#520006321).

\section{REFERENCES}

Alvey, S. and D.E. Crowley, 1996. Survival and activity of an atrazine-mineralizing bacterial consortium in rhizosphere soil. Environ. Sci. Technol., 30: 1596-1603. DOI: 10.1021/es950575

Bentley, R. and T.G. Chasteen, 2002. Microbial methylation of metalloids: Arsenic, antimony and bismuth. Microbiol. Mol. Biol. Rev., 66: 250-271. DOI: 10.1128/MMBR.66.2.250-271.2002
Cai, B., Y. Han, B. Liu, Y. Ren and S. Jiang, 2003. Isolation and characterization of an atrazinedegrading bacterium from industrial wastewater in China. Lett. Applied Microbiol., 36: 272-276. DOI: 10.1046/j.1472-765X.2003.01307.X

Clarkson, D., P.B. Bull and D.J. Moles, 1982. Effect of two granular nematicides on growth and nodulation of Arachis hypogeo L. Plant Soil, 66: 413-416. DOI: $10.1007 /$ BF02183808

De Souza, M.L., J. Seffernick, B. Martinez, M.J. Sadowsky and L.P. Wackett, 1998a. The atrazine catabolism genes atzABC are widespread and highly conserved. J. Bacteriol., 180: 1951-1954. PMID: 9537398

De Souza, M.L., L.P. Wackett and M.J. Sadowsky, 1998b. The atzABC genes encoding Atrazine catabolism are located on a self-transmissible plasmid in Pseudomonas sp. Strain ADP. Applied Environ. Microbiol., 64: 2323-2326. PMID: 9603862

Devers, M., S. Henry, A. Hartmann and F. MartinLaurent, 2005. Horizontal gene transfer of atrazinedegrading genes (atz) from Agrobacterium tumefaciens St96-4 pADP1::Tn5 to bacteria of maize-cultivated soil. Pest Manage. Sci., 61: 870-880. DOI: $10.1002 / \mathrm{ps} .1098$

Downing, H.F., M.E. Delorenzo, M.H. Fulton, G.I. Scott and C.J. Madden et al., 2004. Effects of agricultural pesticides Atrazine, Chlorothalonil and Endosulfan on South Florida microbial assemblages. Ecotoxicology, 13: 245-260. DOI: 10.1023/B:ECTX.0000023569.46544.9f

Faassen, H.G. and G. Lebbink, 1984. Chemical disinfestation and metabolic integrity of soil. Plant Soil, 76: 389-400. DOI: 10.1007/BF02205596

Gauger, W.K., J.M. McDonald, N.R. Adrian, D.P. Mathees and D.D. Walgenbach, 1986. Characterization of a streptomycete growing on organophosphate and carbamate insecticides. Arch. Environ. Contam. Toxicol., 15: 137-141. DOI: 10.1007/BF01059962

Gianessi, L.P. and M.B. Marcelli, 2000. Pesticide use in US crop production: 1997. National Center for Food and Agricultural Policy. http://www.cipm.info/croplife/nationalsummary1997.pdf

Gianessi, L.P. and S. Sankula, 2003. The value of herbicides in US crop production. National Center for Food and Agricultural Policy. http://croplifefoundation.org/Documents/Pesticide $\%$ 20Benefits/Herbicides/HerbBeniFullText.pdf

Gonzalez-Pradas, E., M. Villafranca-Sanchez, F. Del Rey-Bueno, M.D. Urena-Amate and M. FernandezPerez, 2000. Removal of paraquat and atrazine from water by montmorillonite-phosphate crosslinked compounds. Pest Manage. Sci., 56: 565-570. DOI: 10.1002/(SICI)15264998(200006)56:6<565::AID-PS170>3.0.CO;2-V 
Hofman, T.W. and G.J. Bollen, 1987. Effects of granular nematicides on growth and microbial antagonism to Rhizoctona solani. Eur. J. Plant Pathol., 93: 201-214. DOI: 10.1007/BF01998248

Islam, M.S. and M. Tanaka, 2004. Impacts of pollution on coastal and marine ecosystems including coastal and marine fisheries and approach for management: A review and synthesis. Mar. Pollut. Bull., 48: 624-649. DOI: 10.1016/j.marpolbul.2003.12.004

Janssen, D.B., I.J.T. Dinkla, G.J. Poelarends and P. Terpstra, 2005. Bacterial degradation of xenobiotic compounds: Evolution and distribution of novel enzyme activities. Environ. Microbiol., 7: 1868-1882. DOI: 10.1111/j.1462-2920.2005.00966.x

Madigan, M.T., J.M. Martinko, P.V. Dunlap and D.P. Clark, 2005. Brock Biology of Microorganisms, 11th Edn., Benjamin Cummings, Upper Saddle River NJ., ISBN: 978-0132192262, pp: 1088.

Mandelbaum, R.T., D.L. Allen and L. P. Wackett, 1995. Isolation and characterization of a Pseudomonas sp. that mineralizes the s-triazine herbicide atrazine. Applied Environ. Microbiol., 61: 1451-1457. PMID: 16534995

Mandelbaum, R.T., L.P. Wackett and D.L. Allan, 1993a. Mineralization of the s-triazine ring of atrazine by stable bacterial mixed cultures. Applied Environ. Microbiol., 59: 1695-1701. PMID: 8328795

Mandelbaum, R.T., L.P. Wackett and D.L. Allan, 1993b. Rapid hydrolysis of atrazine to hydroxyatrazine by soil bacteria. Environ. Sci. Technol., 27: 1943-1946. DOI: 10.1021/es00046a028

McBride, B.C. and R.S. Wolfe, 1971. Biosynthesis of dimethylarsine by a methanobacterium. Biochem., 10: 4312-4317. PMID: 5126942

Moens, T., M. Araya, R. Swennen and D. Waele, 2004. Enhanced biodegradation of nematicides after repetitive applications and its effect on root and yield parameters in commercial banana plantations. Biol. Fertil. Soils, 39: 407-414. DOI: 10.1007/S00374-004-0726-6

Morel-Chevillet, C., N.R. Parekh, D. Pautrel and J.C. Fournier, 1996. Cross-enhancement of carbofuran biodegradation in soil samples previously treated with carbamate pesticides. Soil Biol. Biochem., 28: 1767-1776. DOI: $10.1016 /$ S00380717(96)00282-9

Osman, K.A., S.M. Al-Rehiayani, M.A. Al-Deghairi and A.K. Salama, 2009. Bioremediation of oxamyl in sandy soil using animal manures. Int. Biodeterior. Biodegrad., 63: 341-346. DOI: 10.1016/j.ibiod.2008.10.008
Radosevich, M., S.J. Traina, Y.L. Hao and O.H. Tuovinen, 1995. Degradation and mineralization of atrazine by a soil bacterial isolate. Applied Environ. Microbiol., 61: 297-302. PMID: 7887609

Robertson, S.M., L.R. Gamble and T.C. Maurer, 1992. Contaminant survey of La Sal Vieja, Willacy County, Texas, 1989. US Fish Wildlife Service. http://library.fws.gov/Pubs2/ci/LaSalVieja1992.pdf ?id=14

Ros, M., M. Goberna, J.L. Moreno, T. Hernandez and C. Garcia et al., 2006. Molecular and physiological bacterial diversity of a semi-arid soil contaminated with different levels of atrazine. Applied Soil. Ecol., 34: 93-102. DOI: 10.1016/j.apsoil.2006.03.010

Runes, H.B., J.J. Jenkins, J.A. Moore, P.J. Bottomley and B.D. Wilson, 2003. Treatment of atrazine in nursery irrigation runoff by a constructed wetland. Water Res., 37: 539-550. DOI: 10.1016/S00431354(02)00310-X

Silver, S. and L.T. Phung, 1996. Bacterial heavy metal resistance: New surprises. Ann. Rev. Microbiol., 50: 753-789. DOI: 10.1146/annurev.micro.50.1.753

Sorensen, K.C., J.W. Stucki, R.E. Warner, E.D. Wagner and M.J. Plewa, 2005. Modulation of genotoxicity of pesticides reacted with redox-modified smectite clay. Environ. Mol. Mut., 46: 174-181. DOI: 10.1002/em.20144

Talaro, K.P., 2008. Foundations in Microbiology, Basic Principles 7th Edn., McGraw-Hill, New York, ISBN: 13: 978-0077263164, pp: 534.

Taylor, A.L, 2003. Nematocides and nematicides-a history. Nematropica, 33: 225-232. http://brokert10.fcla.edu/DLData/NM/NM0000000 9/NM00995444/33_2/Taylor225.pdf

US Environmental Protection Agency, 1984. Methods for organic chemical analysis of municipal and industrial wastewater. US Environmental Protection Agency.

http://www.epa.gov/waterscience/methods/method/ organics/608.pdf

Wackett, L., M. Sadowsky, B. Martinez and N. Shapir, 2002. Biodegradation of atrazine and related striazine compounds: From enzymes to field studies. Applied Microbiol. Biotechnol., 58: 39-45. DOI: 10.1007/s00253-001-0862-y

Wauchope, R.D., 1978. The pesticide content of surface water draining from agricultural fields-a review. J. Environ. Qual., 7: 459-472. http://search.nal.usda.gov/bitstream/10113/30/1/C AIN789179301.pdf 